\author{
B. Zoology \\ ISSN: $2090-0759$ \\ www.eajbs.eg.net
}

\title{
Cytogenetical studies on some River Nile species from polluted and nonpolluted Aquatic habitats
}

\author{
Amany Mahmoud ${ }^{1}$; Mohamed Zowail ${ }^{1}$; Ghada Yossif ${ }^{2}$ and Khaled Sharafeldin ${ }^{1}$ \\ 1- Zoology Dept, Faculty of Science, Benha University \\ 2- Zoology Dept, Faculty of Science, MenufiyaUniversity
}

\begin{abstract}
Shanawan drainage canal is one of the many drainage canals present in Menufiya province, Egypt. It receives sewage water from Kafr Shanawan drainage canal. Also, it receive illegal run-off from sewage and wastes besides sewage of Shebeen Al-koom city. This study is aimed to investigate the frequency of chromosomal damage by using chromosomal aberrations test of head kidney cells in Oreochromis niloticus and Tilapia zillii fish. The study was performed on 5 groups of fish, control and four polluted groups. A and B stations are located before the source of sewage discharge while $\mathrm{C}$ and $\mathrm{D}$ stations are located after the source of sewage. In each group cytological studies were performed. Fishes caught from areas before the sources of sewage showing different types of chromosomal aberrations, including centromeric attenuations, chromatid breaks, chromatid gabs, chromatid deletion, centric fusion and fragmentation. The total aberrations were more obvious among the fishes of the areas after the source of sewage than those of the areas before the source of sewage. It was noted that $O$. niloticus is more sensitive to the effect of pollution than T. zillii. Cytogenetic Studies of the current Work could be used as criteria for pollution intensity, which can be used to avoid its toxic effect on aquatic environment.
\end{abstract}

Keywords:

\section{INTRODUCTION}

Pollution of the aquatic ecosystem is recognized globally as a potential threat to both human and other animal's population which interacts with aquatic environment (Biney et al., 1987), Egypt possesses approximately $5000 \mathrm{~km}$ of irrigation and drainage canals (Redding and Midlen, 1992). Drainage canals were polluted as a result of discharging agricultural drains daily, with insecticides, pesticides, heavy metals, fertilizers, chemicals, sewage and other possible domestic/industrial wastes. The wide indiscriminative use of pesticides in weed and pest control, certainly, results in the pollution of all environmental components including water body (Matter et al., 1992).

Several studies have linked increases in cytogenetic abnormalities in fish and shellfish to polluted environment. This was done largely through laboratory bioassays of polluted water sample in nature (Hooftman and Raat, 1982; Hose et al., 1987; Metcalf, 1988). Mohamed et al., (2008) measured the cytogenetic changes by observing the frequency of chromosomal aberration in the gill cells of the treated Oreochromis niloticus by copper sulfate and lead acetate. Mahrous and Abdou (2001) detected that the environmental water pollution (agricultural waste water or industrial) have significant effects on Oreochromis niloticus and Clarias lazera, which appeared as chromosomal aberration breaks, deletion, and centromeric attenuation in somatic cells. Velmurugan et al. (2009) found that the exposure of Mystus glulio to lambda- 
cyhalothrin for 96h. resulted in an enhancement in the frequency of chromatid breaks, acentric fragments, centromeric fusion, aneuploidy, condensation, sticky plates and ring compared with those in the tap water control. The widely used herbicide $(2,4-$ dichorophenoxy) acetic acid (2,4-D) is evaluated for acute toxicity and stress factors on fresh water fish Abumourad et al. (2006). The percentage of chromosomal aberration was highly significant after treatment with the different herbicides doses .

This current study was carried out to investigate and evaluate the pollution of Shanawan drainage canal and its effects on the health of fishes represented by two cichlids $O$. niloticus and $T$. zillii by using chromosomal aberration test in somatic cells and morphological malformation, which is considered the first sign of the effect of pollution on the fish.

\section{MATERIALS AND METHODS}

\section{Study area:}

Shanawan drainage canal (Menufiya province) as described by Khallaf et al, (1998). The study was performed on 5 groups of fish (Oreochromis niloticus and Tilapia zillii, $132 \pm 10$ gm body weight). Control group fishes were collected by bottom trap (Gobiah) nets by fishermen from baher Shebeen canal. Polluted groups includes Four stations, stations A \& B are located before (upstream) the source of sewage discharge of Shanawan drainage canal while stations C \& D are located after (downstream) the source of sewage.

Fishes from polluted (Shanawan drainage canal) and unpolluted (Baher Shebeen canal) area were collected to study the following parameter.

\section{Chromosomal preparation:}

Mitotic chromosomes were obtained. Fish were injected intraperitoneally $3 \mathrm{hrs}$ before sacrifice with $0.01 \%$ colchicine. Squash technique for kidney tissue described by ALSabti et al. (1983) was used for the preparation of chromosomes with some modification. For each fish, 50 well spreaded metaphases were examined for kidney. Different types of chromosomal aberrations will be recorded.

\section{RESULTS}

The present study showed that the diploid number of chromosomes in Tilapia were $2 n=44$. High percentage of chromosomal abnormalities in head kidney cells of $O$. niloticus and T. zillii were observed clearly in the form of centromeric attenuation ,chromatid breaks, chromatid gaps, chromatid deletions, centric fusion and fragmentation (Fig. 1).

The current results revealed that the values of different types of chromosomal aberration in head kidney cells of $T$. zillii in area B, C and D were significant $(P<$ $0.05)$ than showed in fish of unpolluted area (Table 1). Also, data showed a significant $(P<0.05)$ values of aberrations in fishes caught from areas $\mathrm{C} \& \mathrm{D}$, downstream to sewage source (almost two fold) than in fish of areas A \& B, upstream of sewage source (Table 1). The same results were observed in O. niloticus of the same areas (Table 2). The values of aberration revealed higher number in $O$. niloticus than in $T$. zillii (Table 1\&2). 


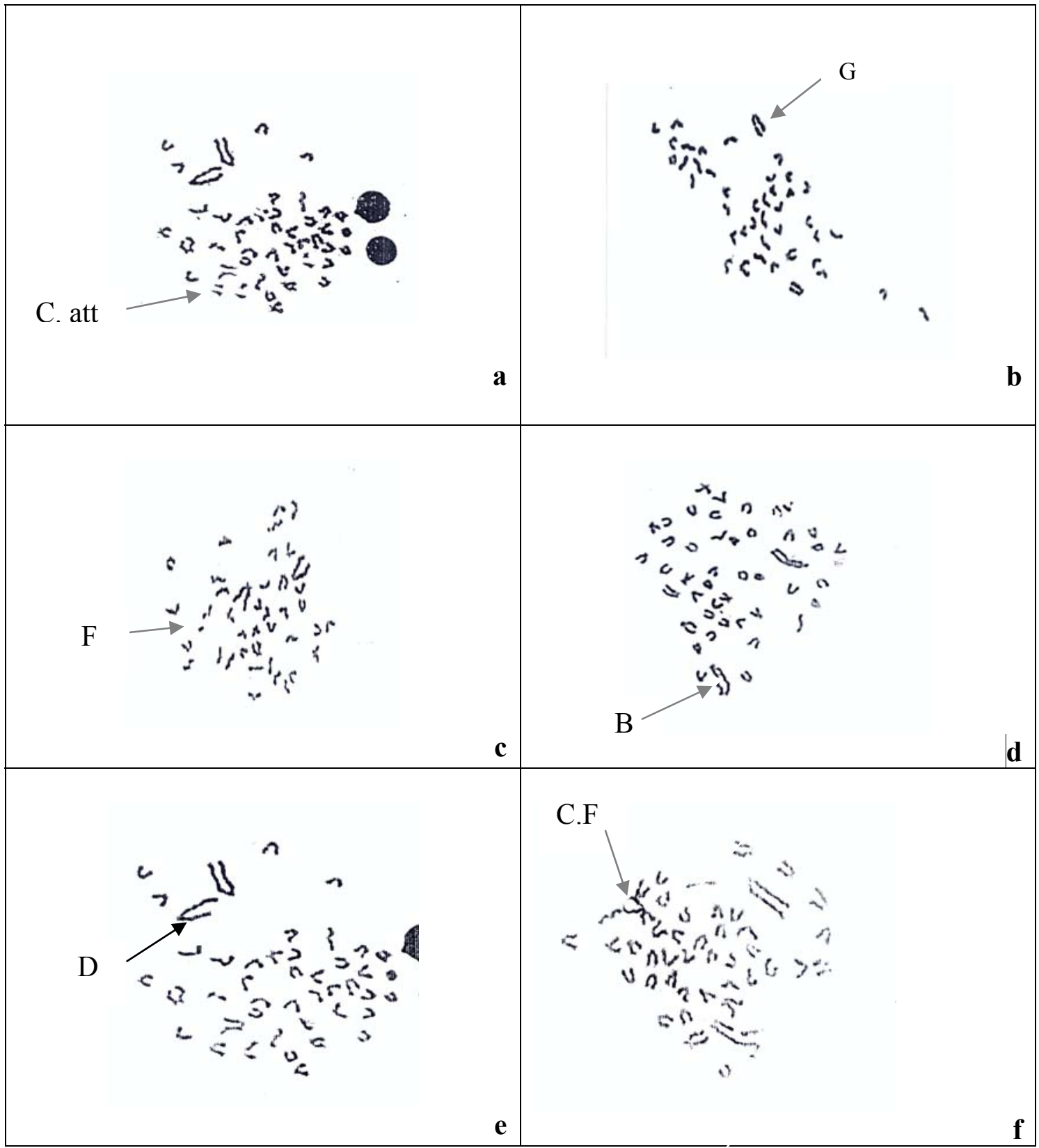

Fig. 1: Types of chromosomal abarration in head kidney cells of $O$. niloticus Showing metaphase a- Centromeric attenution (C. att); b- Gap (G); c- Fragmentation (F) ; d- Break (B); e- Deletion (D); f- Centric Fusion (C.F). 
Table 1: The average values of different types of chromosomal aberrations in head kidney of Tilapia zillii caught from polluted and non-polluted area

\begin{tabular}{|l|l|l|l|l|l|}
\hline \multirow{2}{*}{ Types of chromosomal aberrations } & Control & \multicolumn{4}{|c|}{ Polluted Areas } \\
\cline { 2 - 6 } & & \multicolumn{4}{|c|}{ Mean \pm SE } \\
\cline { 2 - 6 } & & \multicolumn{1}{|c|}{$\mathrm{A}$} & $\mathrm{B}$ & \multicolumn{1}{|c|}{$\mathrm{C}$} & \multicolumn{1}{|c|}{$\mathrm{D}$} \\
\hline Centromeric attenuation & $27.0 \pm 1.34$ & $40.60 \pm 2.40^{*}$ & $44.40 \pm 2.79^{*}$ & $84.60 \pm 4.51^{*} \mathrm{q}$ & $98.80 \pm 4.47^{* \mathrm{q}}$ \\
\hline Chromatid break & $1.60 \pm 0.40$ & $3.80 \pm 0.66^{*}$ & $6.20 \pm 0.86^{*}$ & $12.20 \pm 1.16^{*} \mathrm{q}$ & $20.60 \pm 1.44^{*} \mathrm{q}$ \\
\hline Chromatid gap & $1.40 \pm 0.24$ & $2.20 \pm 0.37$ & $2.40 \pm 0.51$ & $4.60 \pm 0.60^{*} \mathrm{q}$ & $7.00 \pm 0.71^{*} \mathrm{q}$ \\
\hline Fragmentation & $1.80 \pm 0.37$ & $3.00 \pm 0.45$ & $4.20 \pm 0.58^{*}$ & $7.60 \pm 0.81^{*} \mathrm{q}$ & $9.60 \pm 1.03^{*} \mathrm{q}$ \\
\hline Chromatid deletion & $2.80 \pm 0.37$ & $3.40 \pm 0.51$ & $4.60 \pm 0.68$ & $10.00 \pm 0.71^{*} \mathrm{q}$ & $16.20 \pm 1.98^{* \mathrm{q}}$ \\
\hline Centric fusion & $2.00 \pm 0.55$ & $3.80 \pm 0.58$ & $5.00 \pm 0.84^{*}$ & $8.40 \pm 1.03^{*} \mathrm{q}$ & $11.20 \pm 1.20^{* \mathrm{q}}$ \\
\hline Total structural aberrations & $41.60 \pm 2.56$ & $56.80 \pm 9.34$ & $66.80 \pm 4.78$ & $127.40 \pm 5.22^{*} \mathrm{q}$ & $163.40 \pm 5.78^{*} \mathrm{q}$ \\
\hline
\end{tabular}

A , B : Areas before the source of sewage

C, D : Areas after the source of sewage .

S .E :Standard Error

* Significant $(\mathrm{P}<0.05)$ between polluted \&non-polluted

q Significant $(\mathrm{P}<0.05)$ between polluted areas

Table 2: The average values of different types of chromosomal aberrations in head kidney of Oreochromis niloticus caught from polluted and non-polluted area

\begin{tabular}{|c|c|c|c|c|c|}
\hline \multirow{3}{*}{$\begin{array}{c}\text { Types of chromosomal } \\
\text { aberrations }\end{array}$} & Control & \multirow{2}{*}{\multicolumn{4}{|c|}{$\begin{array}{c}\text { Polluted Areas } \\
\text { Mean } \pm \text { SE } \\
\end{array}$}} \\
\hline & & & & & \\
\hline & & $\mathrm{A}$ & $\mathrm{B}$ & $\mathrm{C}$ & $\mathrm{D}$ \\
\hline Centromeric attenuation & $\begin{array}{l}25.80 \pm \\
1.53\end{array}$ & $\begin{array}{l}50.00 \pm \\
2.35\end{array}$ & $51.40 \pm 2.38$ & $100.40 \pm 3.91$ & $113.20 \pm 4.69$ \\
\hline Chromatid break & $2.60 \pm 0.51$ & $6.00 \pm 0.66^{*}$ & $6.20 \pm 0.86^{*} \mathrm{q}$ & $12.20 \pm 1.16^{*} \mathrm{q}$ & $20.60 \pm 1.44{ }^{*} \mathrm{q}$ \\
\hline Chromatid gap & $2.20 \pm 0.37$ & $3.00 \pm 0.55$ & $4.20 \pm 0.58^{*}$ & $7.20 \pm 0.73^{* q}$ & $10.20 \pm 0.97^{*} \mathrm{q}$ \\
\hline Fragmentation & $2.00 \pm 0.45$ & $4.40 \pm 0.51^{*}$ & $6.60 \pm 0.93^{*}$ & $11.80 \pm 1.24^{* \mathrm{q}}$ & $18.00 \pm 1.76^{*} \mathrm{q}$ \\
\hline Chromatid deletion & $3.80 \pm 0.66$ & $6.40 \pm 0.68$ & $10.00 \pm 0.71^{*}$ & $17.00 \pm 0.89^{* \mathrm{q}}$ & $22.80 \pm 1.39^{*} \mathrm{q}$ \\
\hline Centric fusion & $3.80 \pm 0.66$ & $5.00 \pm 0.71$ & $7.80 \pm 0.73^{*}$ & $10.20 \pm 0.86^{*}$ & $15.00 \pm 1.22^{*} \mathrm{q}$ \\
\hline Total structural aberrations & $40.20 \pm 1.77$ & $74.80 \pm 2.40^{*}$ & $89.00 \pm 3.94^{*}$ & $161.00 \pm 4.87^{*} \mathrm{q}$ & $202.40 \pm 7.52^{* \mathrm{q}}$ \\
\hline
\end{tabular}

A, B : Areas before the source of sewage .

C, D : Areas after the source of sewage.

S .E :Standard Error.

* Significant $(\mathrm{P}<0.05)$ between polluted \& non-polluted.

$\mathrm{q}$ Significant $(\mathrm{P}<0.05)$ between polluted areas

\section{DISCUSSION}

Exposure to genotoxic agents may result in mutation, metabolic disorder, damage embryos and reduced fertility (Ghaffar et al., 1994). The use of genotoxicity testing is essential for the assessment of potential livestock toxicity so that, hazard can be controlled.

Cytogenetic analysis of chromosomes has been employed as a biological dosimeter to estimate the effect of genotoxic agents (pollutants) on fish and very useful for direct detection in somatic cells (Yunis, 1983 and Radwan, 1996).

Family Cichliddae represent over $70 \%$ of the Egyptian fish loading and have a number of chromosomes $(2 \mathrm{n}=44)$. Structural aberrations (e.g., chromatid deletion, chromatid gap, chromatid break, centromeric attenuation, fragmentation and centric fusion) were more prominent in the fishes of different polluted areas (Shanawan drainage canal) than those of non-polluted area (Bahr Shebeen). Similar results were recorded by Mohamed et al. (2008) on O. niloticus fish exposed to copper sulfate and lead acetate. They observed that chromatid deletion, stickness and fragments were more frequent than other chromosomal aberrations. Also, Yadav and Trivedi (2009) found that the exposure of Channa punctata $(2 n=32)$ to, mercuric chloride, arsenic 
trioxide and copper sulphate pentahydrate for a Week, kidney cells revealed chromatid and chromosome breaks, chromatid and chromosome gaps, along with ring and di-centric chromosomes. The findings depict genotoxic potential of these metals even in sublethal concentrations.

Our results were in agreement with Velmurugan et al., (2009) who found enhancement in the frequency of chromatid breaks, acentric fragments, centromeric fusions, aneuploidy, condensation, sticky plates and ring, of Mystus glulio fish exposed to a Lambda-cyhalothrin compared with those in the tap water control. Chromosomal aberrations frequency increased regard to increase of concentrations of herbicide, whipsuper (Farag, et al., 2009).

The higher level of chromosomal aberrations in fish from polluted areas may be the result of environmemental contamination caused by industrial emissions or duo to contaminated water with heavy metals and pesticides. Gill cells of the treated fish by copper sulfate and lead acetate displayed lower mitotic activity than that of the control group. Both pollutants were found to be positive inducer of macro-DNA damage which represented by different type of aberrations e.g. chromatid deletions, chromatid gaps, chromatid breaks, fragments, stickness, translocations, ring chromosomes, and centromeric attenuation. Chromatid deletions, stickness and fragments were more frequent than other chromosomal aberrations (Mohamed et al., 2008).

Generally, for both $O$. niloticus and T. zillii there was a significant difference between all polluted areas and the control area. Also, it was clear that O. niloticus is more sensitive to the effect of pollution than T. zillii. So these chromosomal aberration may lead to changes in the genetic component.

Heavy metals are known to be persistent in the aquatic environment and gradually accumulate and magnify through the process known as bioaccumulation and biomagnifications (Malla and Ganesh, 2009).

Awwad (1991) stated that there is a significant increase in the frequency of deletions in grass carp fish exposed to carbarmate insecticide. Mattar et al., (1992), indicated that there was a high significant increase in chromosomal deletion in the kidney cells of grass carp exposed to insecticides. Radwan (1996), also observed that in agricultural pollution, the most dominant aberration were deletion, gaps, euploidy and condensation. Also, Krishnaja and Rege (1982), show that there was a significant increase of the number of gaps in fish Boleophthalmus dussumieri exposed to mitomycin $\mathrm{C}$ and heavy metals mercury, selenium and chromium.

Generally, for both $O$. niloticus and T. zillii, there was a significant difference between all polluted areas and the control area. These chromosomal aberration may lead to changes in the genetic component and concern has been expressed about "genetic consequences of pollution to fish populations exposed to low levels of pollution over prolonged periods (Barker and Rackham, 1979).

Chromosomal aberrations result from abnormalities in DNA duplication during the S phase; this may be due to the interference of the pollutants with nucleotide synthesis (Mattar et al., 1992), leading to malformation of DNA molecules (Landolt and Kocan, 1983). Also, Evans (1977) thought that the chromosomal aberrations also arise as a consequence of miss-repair or of miss-replication of damaged DNA. Also, according to (Natarajan and Obe, 1978), the ultimate lesions responsible for aberration formation are DNA-strand break. So, chromosomal aberration can be used as an indicator of DNA damage. $\mathrm{OH}$ radicals and $\mathrm{O}_{2}$ are considered the most important biologically relevant oxygen species, however they are able to react directly with all kind of cells components including cellular DNA. The oxidative DNA damage introduced by direct reaction of these radicals, leads to aberration on base pairs (Retel et al., 1993). Ammonia concentration in the aquatic habitat may have 
enhanced the toxicity of heavy metals such as copper and zinc (Halle et al., 1989). Therefore, it is believed here, that the presence of ammonia in the canal water was multiplicative to other heavy metals effect which may leads to chromatid aberration. In other studies, Goodale et al., (2008), showed that aquatic chromium is both increased cytotoxic and genotoxic to fish cells.

In the preceded analysis, $O$. niloticus was found to be more susceptible than $T$. zilli. This may be attributed to the behavior of both fish. Thus, where the first is a multiple spawner mouth broader and move frequently than the annual spawner nest guarder Tilapia zillii ( Khallaf et al., 1986).

This evaluated study reveals that the cytogenetic analysis of chromosomes has been employed as a biological dosimeter to estimate the effect of genotoxic agents (aquatic pollutants) on fish and very useful for direct detection in somatic cells. The results of the present study and previous investigations (Mattar et al., 1992; Radwan, 1996 and Abbass et al., 2005) performed either under laboratory or filed conditions, encourage a wider application of cytological studies as an early biological marker of exposed fish to clastogenic pollution in water.

\section{REFERENCES}

Abbass, A.A.; Radwan, H.A.; Ismail, R.S. (2005): Behavioral, chromosomal aberration and hematological change associated with acute nitrite toxicity in African catfish Clarias gariepinus. Veterinary Medical Journal, 53(1): 83-94.

Abumourad, I. M.; El- Sherbeny, K. M.; Farghaly, A. A. (2006): Detection of DNA damage of Clarias gariepinus exposed to 2,4 -D using chromosomal aberrations and RAPD assays. Bulletin of Agriculture, Cairo University, 57( ): $658-700$.

AL-Sabti, K.; Fijan, N. \& Kurelec, B.(1983): A simple and fast technique for chromosomal preparation in fish. Vet. Arch., 53: 283 -290.

Awwad, A.M. (1991): Effect of pollution on haemopoietic cells of fresh water fishes in Qalyobia province. M. Sc. Thesis zoology. Zagazig University, Faculty of Science.

Barker, G. J.\& Rackham,B. D. (1979): The induction of sister-chromatid exchange in cultured fish cells (Ameca splendens) by carcinogenic mutagens. Mut. Res., 68: 381- 387.

Biney,.;Calamari, D.; Membe, T.W.; Naeve, H.; Nyakageni, B. and Saad, M.A. H. (1987): Scientific bases for pollution control in African inland waters. FAO fisheries, 369: 9-23.

Evans,H.J. (1977): Molecular mechanisms in the induction of chromosome aberration. Scott, D.Bridges, B.A.and Sobier / North Holland, Amsterdam, 57-74.

Farag.M.E.; Ramadan, A.A.; Ali, M.A (2009): Cytogenetic and biochemical effects of whip super herbicide toxicity on Nile tilapia (Oreochromis niloticus). Proceedings of the $2^{\text {nd }}$ Global fisheries and Aquaculture Research. Conference, Cairo International Convention Center, 53: 95-79.

Ghaffer, A. E.; Abou-Salem, M. E. and Ashoub,M.M. (1994): Relationship between environmental pollution and incidence of repeat breeder in buffalo-cows. Annals Agric. Moshtoher 32(3): 1715-1728.

Goodale, B. C.; Walter, R.; Pelsue, S. R.; Thompson, W.D.; Wise, S.S.; Winn, R. N.; Mitani, H. and Wise, J. P. (2008): Cytotoxicity and genotoxicity of hexavalent chromium in medaka. Oryzias latipes cells. Aquatic Toxicology.87: (1) 60-67.

Halle, L.W.; Ziegenfuss, M.C.; Bushong, S.J.; Unger, M.A. and Herman, R.L. (1989): Studies of contaminant and water quality effects on striped bass prolarvae and 
yearlings in the Potomac River and Upper Chesapeake Bay in 1988. Transaction of the American Fisheries Society, 118: 619 - 629.

Hooftman, R.N. and Raat, W.K. (1982): Induction anomalies (micronuclei) in the peripheral blood erythrocytes of the eastern mudminow Umbra pygmaea by ethyl methane sulphonate. Mut. Res., 104: 147-152.

Hose, J. E.; Cross, J. N.; Smith, S. G. and Diehl, D. (1987): Elevated circulating erythrocyte micronuclei in fishes from contaminated pites of southern California. Marine Environ. Res. 22: 167- 176.

Khallaf, E.A.; Latif, A.F.A. \& Alnenaei, A.A. (1986): Reproduction of Tilapia nilotica and Tilapia zillii in a Nile Canal and its interaction with the environment. Delta J. Sci., Tanta Univ., Tanta, Egypt, 10: 724- 747.

Khallaf, E. A.; Galal, M. \& Authman, M. (1998): Assessment of heavy pollution and their effects on Oreochromus niloticus in aquatic drainage canals. J. Egypt. Ger. Soc. Zool., Vol. 26 (B), Vertebrate Anatomy and Embryology, 39-74.

Krishnaja, A.P. \& Rege, M.S. (1982): Induction of chromosomal aberration in fish Boleophthalmus dussumieri after exposure in vivo to mitomycin $\mathrm{C}$ and heavy metals mercury, selenium. Mut. Res., 102: 71- 82.

Landolt, M. L. and Kocan, R. M. (1983): Fish cell cytogenetics: A measure of the genotoxic effects of environmental pollutants. In Aquatic toxicology (J. O. Nriagu, ed.) 335-352. John Wiley and Sons Ins.

Mahrous, K. and Abdou, H. (2001): Cytogenetical studies on some Nile fish. J. Egypt. Ger. Soc. Zool., Histology, Histochemistry \& Genetics, 36(C): 133-144.

Malla,T. M.; Ganesh, N. (2009): Cytogenetic and tissue toxicity by synthetic sindoor in fresh water catfish Heteropneustes fossils. Biomedical \& pharmacology Journal, 2(1): 85-89.

Matter, E.E.; ELserafy, S.S.; Zowail, M. E. M. \& Awwad, m.h. (1992): Genotoxic effect of carbamyl insecticide (sevin) on the grass carp Ctenopharygodan idella (VAL). Egypt. J. Histol., 15 (1): 9-17.

Metcalf, C. D. (1988): Induction of micronuclei and nuclear abnormalities in the erythrocytes of mud minnows (Umbro limi) and brown bullheads (Lctalurus nebulosus). Bull. Environ. Contam. Toxicol. 40: 489 - 495.

Mohamed, M. M.; El-fiky, S.A.; Soheir,Y.M.; Abeer, A.I.(2008): Cytogenetic studies on the effect of copper sulfate and lead acetate.pollution on Oreochromis niloticus fish. Journal of cell Biology. 3(2): 51-60.

Natarajan, A. T. \& Obe, G. (1978): Molecular mechanisms involved in the protection of chromosomal aberrations. Mut. Res., 52: 137-149.

Radwan,H. A. (1996): Physiological and genetical changes in some freshwater fishes duo to pollution. M.V. Sc.Thesis. Fac.Vet. Med., Zagazig Univ.

Redding, T.A. \& Midlen, A.B.(1992): Fish production in irrigation canals. FAO fisheries Technical Paper. no. 317. Rome, FAO. 1990.111p.

Retel, J.; Hoebee, B.; Braun, J. E. F.; Lutgerink, J.T.; Akker, E.; Wanamarta, A.H.; Joenje, H. and Lafleur, M.V. M.(1993): Mutational specific of oxidative DNA damage. Mut. Res., 299: 165-182.

Velmurugan, B.; Ambrose, T.; Selvanayagam, M.. (2006): Genotoxicity evaluation of Lambda - cyhalothrin in Mystus gulio. Journal of Environmental Biology. 27(2): 247-250.

Yadav, K.K.; Trivedi, S. P. (2009): Chromosomal aberrations in a fish,Channa punctata after in vivo exposure to three heavy metals. Mutation Research, Genetic Toxicology and Environmental Mutagenesis 1: 7-12.

Yunis, J. J. (1983): The chromosomal basis of human Neoplasia. Science, 221: 227236. 


\title{
ARABIC SUMMARY
}

\author{
دراسة وراثية على بعض أسماك النيل في بيئات مائية ملوثة وطبيعية

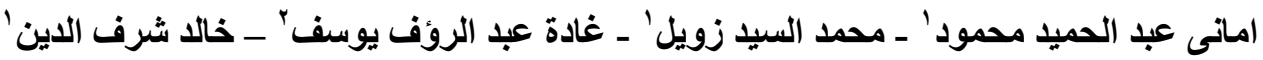 \\ 1 - قسم علم الحيوان - كلية العلوم - جامعة بنها \\ r- ا قسم علم الحيوان - كلية العلوم - جامعة المنوفية
}

اعتمدت هذه الدراسة على دراسة تأثثير التلوث المائي لمصرف شنوان التابع لمحافظة المنوفية لما

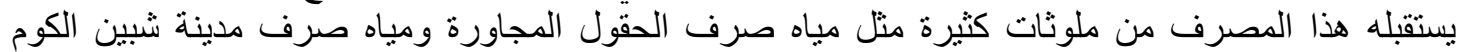

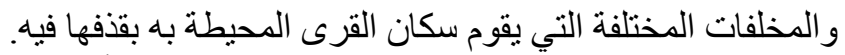

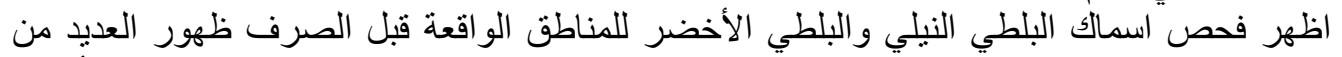

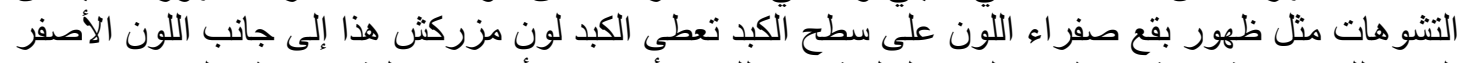

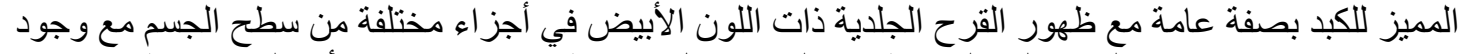

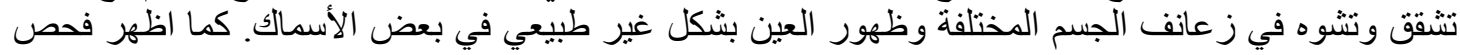

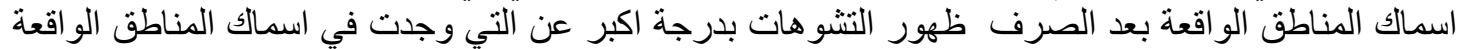

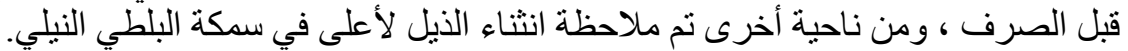

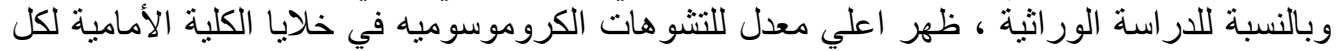

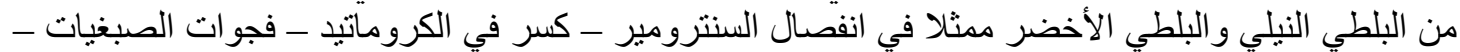

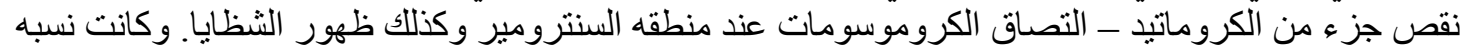

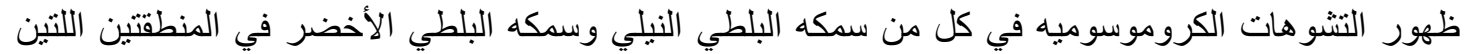

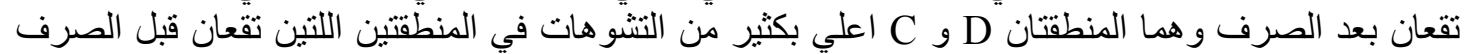

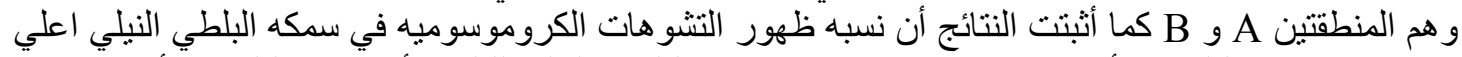

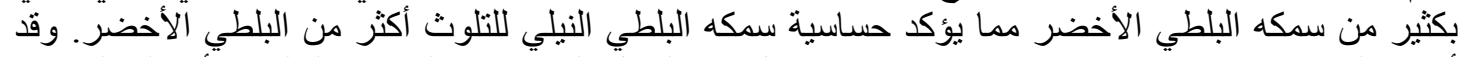

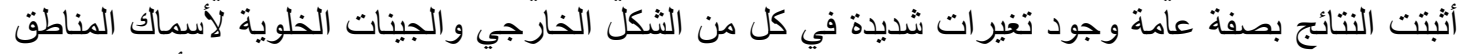

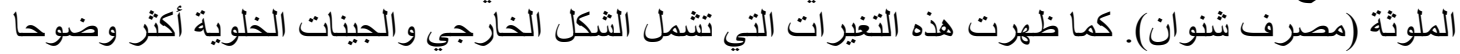

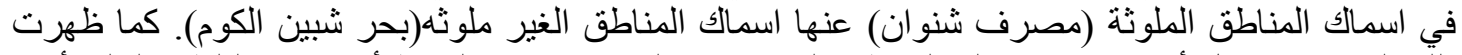

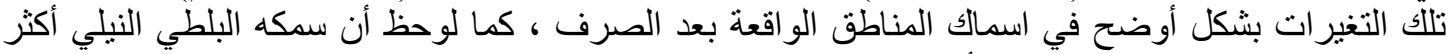

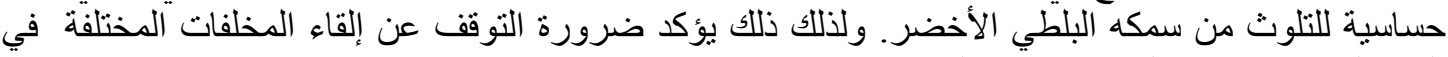
البيئة المائية و تحريم الصيد من هذه المصنارف. 